\title{
Influence of bioturbation on the biogeochemistry of littoral sediments of an acidic post-mining pit lake
}

\author{
S. Lagauzère ${ }^{1, *}$, S. Moreira ${ }^{1}$, and M. Koschorreck ${ }^{1}$ \\ ${ }^{1}$ UFZ - Helmholtz Centre for Environmental Research, Department of Lake Research, Brückstrasse 3a, \\ 39114 Magdeburg, Germany \\ " present address: University of Cologne, BioZentrum, Institute for Zoology, General Ecology and Limnology, \\ Zülpicherstrasse 47b, 50674 Cologne, Germany
}

Received: 16 September 2010 - Published in Biogeosciences Discuss.: 11 October 2010

Revised: 21 January 2011 - Accepted: 8 February 2011 - Published: 14 February 2011

\begin{abstract}
In the last decades, the mining exploitation of large areas in Lusatia (Eastern Germany) but also in other mining areas worldwide has led to the formation of hundreds of pit lakes. Pyrite oxidation in the surrounding dumps makes many such lakes extremely acidic $(\mathrm{pH}<3)$. The biogeochemical functioning of these lakes is mainly governed by cycling of iron. This represents a relevant ecological problem and intensive research has been conducted to understand the involved biogeochemical processes and develop bioremediation strategies. Despite some studies reporting the presence of living organisms (mostly bacteria, algae, and macroinvertebrates) under such acidic conditions, and their trophic interactions, their potential impact on the ecosystem functioning was poorly investigated. The present study aimed to assess the influence of chironomid larvae on oxygen dynamics and iron cycle in the sediment of acidic pit lakes. In the Mining Lake 111, used as a study case since 1996, Chironomus crassimanus (Insecta, Diptera) is the dominant benthic macro-invertebrate species and occurs at relatively high abundances in shallow water. A 16-day laboratory experiment using microcosms combined with high resolution measurements (DET gel probes and $\mathrm{O}_{2}$ microsensors) was carried out. The burrowing activity of $C$. crassimanus larvae induced a 3-fold increase of the diffusive oxygen uptake by sediment, indicating a stimulation of the mineralization of organic matter in the upper layers of the sediment. The iron cycle was also impacted (e.g. lower rates of reduction and oxidation, increase of iron-oxidizing bacteria abundance, stimulation of mineral formation) but with no significant effect on the iron flux at the sediment-water interface, and thus
\end{abstract}

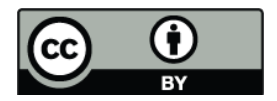

Correspondence to: S. Lagauzère (lagauzere@gmail.com) on the water acidity budget. This work provides the first assessment of bioturbation in an acidic mining lake and shows that its influence on biogeochemistry cannot be neglected.

\section{Introduction}

As a consequence of mining activities in lignite areas, the filling of abandoned sites by groundwater and weathering water frequently leads to the formation of acidic lakes. Compared to most natural lakes, these ecosystems are characterized by low primary production and nutrient concentrations, a high solubility of metals and simple food webs (Geller et al., 1998). In Germany about 500 lignite pit lakes exist of which about $50 \%$ have been initially acidic (Schultze et al., 2009). The water can reach extremely low $\mathrm{pH}$ values (2-3), which represents a highly preoccupant environmental problem. During the last few decades, numerous studies have permitted to describe the biogeochemical functioning of these acid mining pit lakes and to currently consider bioremediation strategies (e.g. Peine et al., 2000; Knöller et al., 2004; Meier et al., 2004; Kamjunke et al., 2005; Blodau, 2006; Koschorreck et al., 2007; Geller et al., 2009). The acidity of lake water is a result of the weathering of pyriteand marcasite-enriched surrounding dumps through the production of $\mathrm{SO}_{4}^{2-}, \mathrm{Fe}^{2+}$ and protons. Subsequent oxidation of $\mathrm{Fe}^{2+}$ leads to the formation of $\mathrm{Fe}$ (III) minerals that precipitate and settle on the sediment surface. Depending on oxygen and organic matter availability, diagenetic processes occurring in the top sediments also play an important role in iron and sulfur cycles. Indeed, under anoxic conditions, microbial reduction of $\mathrm{Fe}(\mathrm{III})$ and to a lesser extent $\mathrm{SO}_{4}^{2-}$ removes protons from the water which creates alkalinity. The

Published by Copernicus Publications on behalf of the European Geosciences Union. 
different factors controlling microbial oxidizing and reductive processes within top sediments are thus crucial for the dynamics of acidity generation and consumption, and as a consequence, for the long-term development of acidic mining lakes and their watersheds (Blodau, 2006).

Among other parameters, micro-organisms living in the sediments of most aquatic ecosystems can be influenced by the bioturbation of sediment-dwelling infauna. Through their burrowing, feeding, irrigating, breathing or defecating activities, these organisms induce physical, chemical and biological modifications which can directly (e.g. grazing, gardening) or indirectly (e.g. modifications of oxygen distribution and nutrient availability) affect microbial communities (Kristensen, 2000; Mermillod-Blondin and Rosenberg, 2006). In the case of extremely acidic mining lakes, the conditions are not favourable for a high biodiversity. These lakes are fishfree and only few benthic invertebrate species are known to colonize the sediments (Wollmann et al., 2000; Rodriguez and Scharf, 2001). Most of them are aquatic insects, predominantly chironomid larvae, which can reach relative high densities in some lakes. These organisms appear therefore to be important as primary consumers and/or top-predators (Lessmann et al., 1999; Wollmann et al., 2000; Rodriguez, 2001). Although some studies have dealt with their distribution patterns or their ecology in acidic mining environments (e.g. Hünken and Mutz, 2007), their influence on the sediment biogeochemistry has never been investigated. Nevertheless, in other environments, it has been clearly demonstrated that chironomid larvae increase nutrient fluxes and oxygen availability in the top sediments providing microniches with various oxygen and redox gradients, and then influence microbial diagenetic reactions (e.g. Svensson and Leonardson, 1996; Svensson, 1997; Kajan and Frenzel, 1999; Brune et al., 2000; Stief and De Beer, 2002; De Haas et al., 2005; Stief et al., 2005; Polerecky et al., 2006; Lewandowski et al., 2007; Stief, 2007). The main effect of chironomid larva bioturbation on the iron cycle is probably indirect. Indeed, local conditions in the sediment are determinant for the physicochemical speciation of metals and then for their mobility and distribution. Through changes of the redox conditions, macrofauna bioturbation modifies the chemical balance of metals and then their partitioning between aqueous and solid phases (Krantzberg, 1985). Precipitation in bottom sediment can also be favoured by stimulation of certain microbial communities as metal-reducers or sulphate-reducers (Warren and Haack, 2001). As regard to these considerations, it appears crucial to assess the influence of bioturbation in acidic mining lakes.

The aim of the present study was to investigate the role of Chironomus crassimanus larvae on the biogeochemistry of the Mining Lake 111 (Lusatia, Germany), a lake which has been used as a study case since 1996 . This species has largely colonized the sediment and appears to be the most dominant or even the unique benthic macro-invertebrate present in this lake (Rodriguez and Scharf, 2001). Our hypothesis was that
Table 1. Chemical characteristics of the water of the Mining Lake 111 , July $2008(N=4)$. Means \pm SD of samples corresponding to different water depth $(0,1.5,4,6 \mathrm{~m}) . \mathrm{DOC}=$ dissolved organic carbon; $\mathrm{TOC}=$ total organic carbon; $\mathrm{TIC}=$ total inorganic carbon; $\mathrm{DIN}=$ dissolved inorganic nitrogen; $\mathrm{SRP}=$ soluble reactive phosphorus; $\mathrm{TP}=$ total phosphorus.

\begin{tabular}{lrlr}
\hline $\begin{array}{l}\text { Chemical } \\
\text { species }\end{array}$ & Concentrations & $\begin{array}{l}\text { Chemical } \\
\text { species }\end{array}$ & Concentrations \\
\hline Cations & $\left(\mathrm{mg} \mathrm{L}^{-1}\right)$ & Nutrients & $\left(\mathrm{mg} \mathrm{L}^{-1}\right)$ \\
\hline $\mathrm{Ca}^{2+}$ & $216 \pm 1.7$ & $\mathrm{NH}_{4}^{+-}-\mathrm{N}$ & $2.22 \pm 0.1$ \\
$\mathrm{Fe}^{2+}$ & $2.29 \pm 1.5$ & $\mathrm{NO}_{3}^{-}-\mathrm{N}$ & $0.25 \pm 0.0$ \\
$\mathrm{~K}^{+}$ & $3.17 \pm 0.2$ & $\mathrm{Si}$ & $11.0 \pm 0.3$ \\
$\mathrm{Mg}^{2+}$ & $25.0 \pm 0.4$ & $\mathrm{SRP}$ & $0.003 \pm 0.0$ \\
$\mathrm{Na}^{+}$ & $6.42 \pm 0.1$ & $\mathrm{TP}$ & $<0.006$ \\
\hline $\mathrm{Anions}^{2-}$ & $\left(\mathrm{mg} \mathrm{L}^{-1}\right)$ & $\mathrm{Metals}$ & $\left(\mathrm{mg} \mathrm{L}^{-1}\right)$ \\
\hline $\mathrm{SO}_{4}^{2-}$ & $1290 \pm 30$ & $\mathrm{Al}-$ total & $36.4 \pm 0.7$ \\
& & $\mathrm{Al}-$ dissolved & $34.7 \pm 0.8$ \\
\hline Carbon & $\left(\mathrm{mg} \mathrm{L}^{-1}\right)$ & $\mathrm{Fe}-$ total & $155 \pm 2.1$ \\
\hline DOC & $1.17 \pm 0.4$ & $\mathrm{Fe}-$ dissolved & $149 \pm 3.3$ \\
TOC & $1.75 \pm 0.9$ & $\mathrm{Mn}$ & $2.78 \pm 0.0$ \\
TIC & $<0.5$ & $\mathrm{Ni}$ & $0.20 \pm 0.0$ \\
& & $\mathrm{Zn}$ & $0.89 \pm 0.0$ \\
\hline
\end{tabular}

bioturbation enhances iron cycling at the sediment-water interface and thus, has an influence on the lakes acidity budget. To study the influence of chironomid bioturbation on iron and oxygen turnover we conducted a laboratory experiment using microcosms combined with high resolution measurements applying Diffusive Equilibration in Thin-films (DET) gel probes and $\mathrm{O}_{2}$ microsensors (Koschorreck et al., 2003).

\section{Material and methods}

\subsection{Sediment and organism sampling}

A laboratory experiment was carried out using intact sediment cores and organisms directly collected in the Mining Lake 111 (ML-111), in the Lusatian lignite mining area in eastern Germany. This small lake (surface area: 10.7 ha, mean/maximal depth: $4.5 / 10.5 \mathrm{~m}$ ) is characterized by very low $\mathrm{pH}$ (2.6) and high ionic strength of the water (Table 1). The sampling location was chosen as regard of the highest abundances of chironomid larvae measured in the lake in June 2008 (Fig. 1). It corresponds to the littoral zone (water depth of $1.5-2 \mathrm{~m}$ ) of the southern part of the lake. The sediment cores $(\varnothing=9 \mathrm{~cm})$ were sampled from a floating platform by means of a gravity corer (UWITEC, Mondsee, Austria) extended by a telescopic bar. They were adjusted to obtain final cores of $20 \mathrm{~cm}$ height of sediment and $10 \mathrm{~cm}$ height of water, and sealed with a plastic stopper to be transported to 


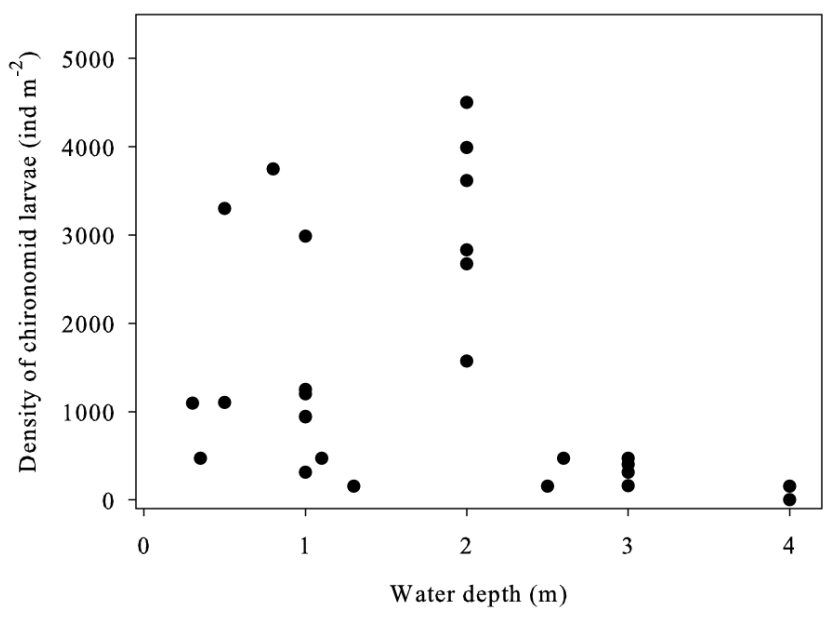

Fig. 1. Density of chironomid larvae as function of water depth in the littoral area of the ML-111 (June-July 2008). The sediment samples were collected following transects at 5 different characteristic areas of the lake.

the laboratory within $4 \mathrm{~h}$. During coring and transport, the overlying water remained clear suggesting that minimal disruptions occurred in the sediment cores.

The chironomid larvae were collected by sieving of several additional sediment samples through a $250-\mu \mathrm{m}$ mesh. The taxonomic identification of Chironomus crassimanus was confirmed by Xavier-François Garcia (IGB, Berlin, Germany) from a significant sample of larval and adult individuals. The larvae were afterwards maintained at the laboratory in a large aquarium under the future experimental conditions for 6 weeks. They were fed daily with around $4 \mathrm{mg}$ ind $^{-1}$ of TetraMin ${ }^{\circledR}$ flakes (Tetra Werke, Melle, Germany) from a suspension of $10 \mathrm{~g} \mathrm{~L}^{-1}$. In these conditions, emergences of adults occurred and a new generation of chironomids was obtained. Two days before the beginning of the experiment, a sufficient number of 3rd and 4th instar larvae were collected in a new aquarium and were starved before their addition to experimental microcosms. To put in evidence the effect of bioturbation, 40 chironomid larvae were added to each core devoted for their observation, that represents a density of 6250 ind $\mathrm{m}^{-2}$ which was slightly higher than the maximal natural densities measured in the lake (Fig. 1).

\subsection{Microcosm set-up}

A total of 16 sediment cores were brought back from ML111 to the laboratory. They were separated in 4 batches of 4 replicates placed in independent beakers with circulating and aerated water ( $>90 \%$ oxygen saturation) from the sampling area. The 4 beakers were themselves placed in a large tank containing temperature-controlled water to maintain a constant temperature in the microcosms. After 5 days of acclimation under laboratory conditions, 8 cores (i.e. 2 batches) were defaunated by bubbling the overlying water with $\mathrm{N}_{2}$ for
$1 \mathrm{~h}$ and subsequent storage with a sealing stopper for $24 \mathrm{~h}$. The anoxia induced by this procedure forced the chironomid larvae inhabiting the sediment to reach the water column where they were removed with a pipette (Andersen and Kristensen, 1992). The cores were afterwards immediately put back into the incubation system under oxic conditions. The first defaunated batch received no other treatment and referred to "defaunated" condition (D-cores). The second one was devoted to chironomid larva addition and referred to "chironomid" condition (Chir-cores). The 8 remaining cores (i.e. 2 other batches) were kept intact from their sampling into the lake to their placement in the incubation system and referred to "control" conditions: 4 cores for initial conditions and 4 cores for final conditions (C-cores). DET gel probes (see below) were deoxygenated by $\mathrm{N}_{2}$-bubbling for $2 \mathrm{~h}$ and then gently inserted into the sediment. After 10 days of equilibration, the experiment started with: (i) the addition of chironomid larvae in Chir-cores, (ii) the first water sampling in all cores, and (iii) the first series of measurements (e.g. oxygen profiles, DET and sediment sampling) in C-cores. After 16 days of incubation, the same measurements were performed in all the remaining cores. The experiment was limited to a short period of 16 days in order to avoid repeated handling in the aquaria due to the replacement of emergent larvae (the life cycle of C. crassimanus is around 25 days at $21^{\circ} \mathrm{C}$, personal observation at the laboratory). Losses of water due to evaporation were daily compensated by adding distilled water whereas volumes removed for sampling were systematically compensated by adding filtered water from the sampling site.

\subsection{Bioturbation observations}

Independently of the experiment, a pre-test was performed to estimate bioturbation intensity of Chironomus crassimanus larvae in the sediment of ML-111. The experimental setup was exactly the same as the one previously described for Chir-treatment (e.g. number of replicates, water circulation, density of larvae). Before introducing larvae in the water column, $2 \mathrm{~g}$ of green luminophores $\left(\varnothing=63 \mathrm{~mm}, \lambda_{\text {excitation }}=\right.$ $450 \mathrm{~nm}, \lambda_{\text {emission }}=520 \mathrm{~nm}$, Geologish-Paleontologisches Institut und Museum der Universität Kiel, Germany) were deposited at the sediment surface. To check the redistribution of tracers under the effects of chironomid displacements, the first $7 \mathrm{~cm}$ of sediment cores were gently sliced into 14 layers of $0.5 \mathrm{~cm}$ after 16 days. The sediment was dried at $105^{\circ} \mathrm{C}$ for $48 \mathrm{~h}$. From each layer, three subsamples were retrieved for counting luminophores under an epifluorescence microscope. 


\subsection{Analyses of the water column}

Temperature, conductivity, oxygen concentration, oxygen saturation and $\mathrm{pH}$ were directly measured in the water column of each microcosm on days $1,4,8,11$ and 16 using multiparameter probes. Five different water samples were also collected when the aforementioned measurements were taken for analyses of (i) total iron $(\mathrm{Fe})$ and aluminium (Al) concentrations by ICP-OES, (ii) ammonium $\left(\mathrm{NH}_{4}^{+}\right)$, silica and soluble reactive phosphorus (SRP) by continuous flow analysis (CFA), (iii) sulfate $\left(\mathrm{SO}_{4}^{2-}\right)$ by single column ion chromatography (Herzsprung et al., 2006) and (iv) total phosphorus (TP) by photometry (ISO 6878:2004, 2004).

\subsection{Oxygen profiles}

On day 1 for C-cores and on day 16 for D- and Chircores, microprofiles of dissolved oxygen were measured using software controlled microelectrodes mounted on a motor driven micromanipulator (UNISENSE, Aarhus, Denmark). For each core, the mean diffusive oxygen uptake (DOU) of sediment was calculated from 3 repeated profiles using the PROFILE software (Berg et al., 1998) which is based on the Fick's first law of diffusion with temperature-corrected diffusion coefficient (Li and Gregory, 1974). This model fits an overall profile between the sediment-water interface and within the sediment down to the oxygen $0 \%$ level. The DOU of sediment is largely used to estimate the organic matter mineralization occurring in early diagenesis processes, and it is therefore considered as a relevant indicator of the global functioning of the sediment.

In $\mathrm{C}$ - and Chir-cores, the oxygen microsensor occasionally intersected burrow sections providing irregular profiles. These profiles were intentionally rejected for further analysis and measurements were repeated until at least 3 regular profiles were obtained in each core (i.e. 12 profiles for each treatment). Therefore, advective uptake of oxygen through burrow walls driven by bioirrigation was not estimated.

\subsection{Sampling and analysis of DET gel probes}

Directly after the oxygen microprofile measurements, the DET gel probe was gently removed from the sediment (i.e. after 10 days of deployment for C-cores and 26 days for D- and Chir-cores). The constrained DET probes (DGTresearch, Lancaster, UK) consisted of small separated gel strips with a millimetric resolution enabling to measure high resolution profiles of dissolved iron in the sediment. Each gel strip was eluted in $500 \mu \mathrm{L}$ of acid distilled water $(\mathrm{pH} 2.5)$ for $24 \mathrm{~h}$ at $4{ }^{\circ} \mathrm{C}$ in the dark. Two $100 \mu \mathrm{L}$ subsamples were afterwards transferred to (1) $100 \mu \mathrm{L}$ of $1 \mathrm{M} \mathrm{HCl}$ for measurement of $\mathrm{Fe}^{2+}$ concentration, and (2) $100 \mu \mathrm{L}$ of $0.5 \mathrm{M}$ of hydroxylamine-hydrochloride in $1 \mathrm{M} \mathrm{HCl}$ for measurement of total reactive Fe. After $30 \mathrm{~min}, 50 \mu \mathrm{L}$ of each extract was transferred to $2.5 \mathrm{~mL}$ of ferrozine solution before its mea- surement by photometry at 400 and $650 \mathrm{~nm}$ for $\mathrm{Fe}^{2+}$ and total $\mathrm{Fe}$, respectively (Koschorreck et al., 2003). $\mathrm{Fe}^{3+}$ concentrations were obtained by subtracting $\mathrm{Fe}^{2+}$ concentration values from total $\mathrm{Fe}$ ones.

As previously described for oxygen measurements, averaged iron profiles were simulated using the PROFILE software (Berg et al., 1998) to estimate turnover rates and fluxes of ferrous and ferric ion within the sediment of each treatment (4 replicates). In this case, boundary conditions were the concentration in the overlying water at the top and an absence of flux in deeper sediment.

Geochemical equilibrium calculations were carried out using PHREEQC (Parkhust and Appelo, 1999). Speciation calculations were used to establish the saturation indexes of different iron minerals in order to explain the $\mathrm{Fe}^{2+} / \mathrm{Fe}^{3+}$ distribution observed at $5 \mathrm{~cm}$ depth in the sediment. The redox potential was calculated from the measured iron profiles. Then, the speciation was performed and the saturation indices were analyzed to determine which minerals could precipitate.

\subsection{Analysis of the sediment}

Finally, after gently removing the water column, the top of the sediment cores was carefully sliced in 4 layers of 0 $1,1-2,2-4$ and $4-7 \mathrm{~cm}$. From each layer, sub-samples of sediment were separated for (i) weighting and drying $\left(105^{\circ} \mathrm{C} / 24 \mathrm{~h}\right)$ to estimate water content, (ii) counting of $\mathrm{Fe}$ oxidizing and Fe-reducing bacteria using the MPN ("most probable number") method, and (iii) analyzing the main solid chemical species: $\mathrm{Fe}, \mathrm{Al}$, and $\mathrm{Mn}$ by ICP-OES; $\mathrm{C}, \mathrm{N}$, and $\mathrm{S}$ by high temperature combustion using an element analyzer (Vario EL, Elementar), silicates by wavelength dispersive Xray fluorescence analysis (Siemens SRS 3000) (Koschorreck et al., 2007).

Viable numbers of iron reducing bacteria (FeRB) and iron oxidizing bacteria $(\mathrm{FeOB})$ were determined by a most probable number technique in microplates (Wendt-Potthoff and Koschorreck, 2002). MPN cultures were incubated at $28^{\circ} \mathrm{C}$ for 6 weeks. Growth was judged either from the formation of brown precipitates $(\mathrm{FeOB})$ or the formation of $\mathrm{Fe}^{\mathrm{II}}(\mathrm{FeRB})$. MPN and their confidence limits were calculated using the software of Klee (1993).

\subsection{Statistical analyses}

All statistical analyses were performed using the STATISTICA ${ }^{\circledR}$ software package (StatSoft, Inc., Tulsa, OK, USA). Before each analysis, the normality (Shapiro-Wilk test) and homogeneity of data variance (Levene test) were tested. It was repeated after log-transformation of data when these assumptions were not first found. A significance level of 5\% was applied to all analyses. The data from water measurements were analyzed by repeated-measures ANOVAs (RM-ANOVA) followed by LSD Fisher's post hoc comparison tests. The jarosite dissolution rate estimated 
from sulfate concentrations in the water, the diffusive oxygen uptake rate estimated from oxygen profiles, and the analytical data for sediment phase were analyzed by one-way ANOVAs followed by LSD Fisher's post hoc comparison tests. The MPN data were analyzed by two-way ANOVAs (treatment $x$ depth) followed by LSD Fisher's post hoc comparison tests.

\section{Results}

\subsection{Observations of chironomid larva behavior}

As soon as the chironomid larvae were deposited at the sediment surface of Chir-cores, they directly burrowed tubes and buried into the sediment to finally only let tube openings visible after some minutes. As in control cores, we could observe from the aquarium sides that larvae reached maximal depth of around $4-5 \mathrm{~cm}$ but seemed to stay mainly in their burrows directly under the sediment surface $(2 \mathrm{~cm})$. These observations were confirmed by the luminophore counting technique used in the pre-test. After 16 days, almost all the luminophores were regained in the first $2 \mathrm{~cm}$ of sediment: $53 \%( \pm 1.2)$ in the $0-0.5 \mathrm{~cm}$ layer, $38 \%( \pm 2.3)$ in the $0.5-$ $1 \mathrm{~cm}$ layer, $6 \%( \pm 0.9)$ in the $1-1.5 \mathrm{~cm}$ layer, and $1.6 \%( \pm 0.1)$ in the $1.5-2 \mathrm{~cm}$ layer. Beneath $2 \mathrm{~cm}$, few luminophores were also punctually observed. From all the measurements, the maximal depth with occurrence of luminophores was $6 \mathrm{~cm}$, reflecting a deeper exploration of the sediment by the larvae.

\subsection{Analyses of the water column}

The temperature was maintained at $21.5 \pm 1.2{ }^{\circ} \mathrm{C}$, the dissolved oxygen concentration at $7.7 \pm 0.3 \mathrm{mg} \mathrm{L}^{-1}$, the $\mathrm{pH}$ at $2.6 \pm 0.1$, and the conductivity at $3.72 \pm 0.05 \mathrm{mS} \mathrm{cm}^{-1}$ throughout the experiment. No significant treatment-related differences were observed for any of these water quality parameters between the sampling days (RM-ANOVAs: $p>$ 0.05).

The evolution of total Fe, total Al, SRP, total P, silicates, sulfate and ammonium concentrations in the water column during the experiment is presented in Fig. 2. For all measured parameters, the statistical analyses show effects of treatment, time, and treatment $\times$ time (RM-ANOVAs: $p<0.05$ ). For clarity and interest, only significant differences observed between undisturbed (D-) and bioturbated (Chir-) cores for each time of sampling were indicated on the graphs (Fisher's LSD test: $p<0.05$; Fig. 2). Although chironomids moderately increased $\mathrm{Fe}, \mathrm{Al}$, silicate or sulfate concentrations, their influence on total $\mathrm{P}$ and ammonium concentrations was more marked, particularly at the end of the experiment. The rates of sulfate efflux from the sediment were $335 \pm 17,230 \pm 36$ and $381 \pm 36 \mathrm{nmol} \mathrm{cm}^{-3} \mathrm{~d}^{-1}$ for C-, D-, and Chir- treatments, respectively.

\subsection{Dissolved oxygen uptake}

Mean oxygen profiles and the vertical distribution of oxygen consumption are reported in Fig. 3. In the absence of chironomids (D-cores), there was a near linear oxygen gradient down to $0.31 \mathrm{~cm}$ where most of the oxygen consuming activity was located. In untreated cores (C-cores), where chironomid density was around 2700 ind $\mathrm{m}^{-2}$, the oxygen penetration was reduced to $0.26 \mathrm{~cm}$ and the maximal DOU was slightly higher than in D-cores. This effect was more pronounced in the Chir- treatment (density of $6250 \mathrm{ind} \mathrm{m}^{-2}$ ), where also the shape of the profile was clearly different. The oxic layer was only $0.21 \mathrm{~cm}$ thick and the DOU was more evenly distributed throughout the profile. By comparing total DOU (flux at the sediment-water interface), statistical analyses showed significant differences between all treatments (ANOVA: $F_{3,25}=18.1, p<0.05$; Fisher's LSD test: $p<0.05)$. The mean value was 1.3 and 3.3 times higher in presence of chironomids $\left(17.5 \times 10^{-3}\right.$ and $43.8 \times$ $10^{-3} \mathrm{nmol} \mathrm{O}_{2} \mathrm{~cm}^{-2} \mathrm{~s}^{-1}$, respectively for $\mathrm{C}$ - and Chir-cores) than in defaunated sediment $\left(13.1 \times 10^{-3} \mathrm{nmol} \mathrm{O}_{2} \mathrm{~cm}^{-2} \mathrm{~s}^{-1}\right.$ for D-cores).

Assuming that the oxygen uptake in the upper part of the sediment was due to organic matter (OM) oxidation while the oxygen uptake at the oxic-anoxic boundary in the sediment was mainly due to the oxidation of upward diffusing $\mathrm{Fe}^{2+}$ (Revsbech and Jørgensen, 1986), the PROFILE modelling permits the following estimations: $21 \%$ and $79 \%$ of DOU were related to $\mathrm{OM}$ and $\mathrm{Fe}$ oxidation, respectively, in defaunated sediment (D-cores), whereas inversely $74 \%$ and $26 \%$ of DOU were related to OM and Fe oxidation, respectively, in bioturbated sediment (Chir-cores).

\subsection{Iron profiles}

The dissolved iron profiles (Fig. 4) showed low concentrations of ferric iron, high concentrations of ferrous iron in deeper sediment layers and an upward diffusive gradient towards about $5 \mathrm{~cm}$ sediment depth. Above this depth and in the water column dissolved iron concentrations were low and uniform. The data imply (i) a production of ferrous iron in suboxic sediment layers (probably mobilisation from $\mathrm{Fe}(\mathrm{III})$ oxyhydroxides by microbial reduction), (ii) followed by its consumption in deeper sediment through a nearly complete removal of upward diffusing $\mathrm{Fe}^{2+}$, and (iii) no diffusive flux of dissolved iron over the sediment-water interface.

From ferrous iron profiles in defaunated sediment (Dcores), the PROFILE modelling separated 4 distinct zones from the top to the bottom of the sediment: (i) on the first $4 \mathrm{~cm}$, a zone of no significant consumption, (ii) between 4 and $8 \mathrm{~cm}$, a zone of high consumption, probably due to iron oxidation and precipitation, (iii) from 8 to $11 \mathrm{~cm}$, a zone of high production, probably due to iron reduction, (iv) and deeper, a zone of lower production. In bioturbated sediment (Chir-cores), only two zones were defined by the model: 

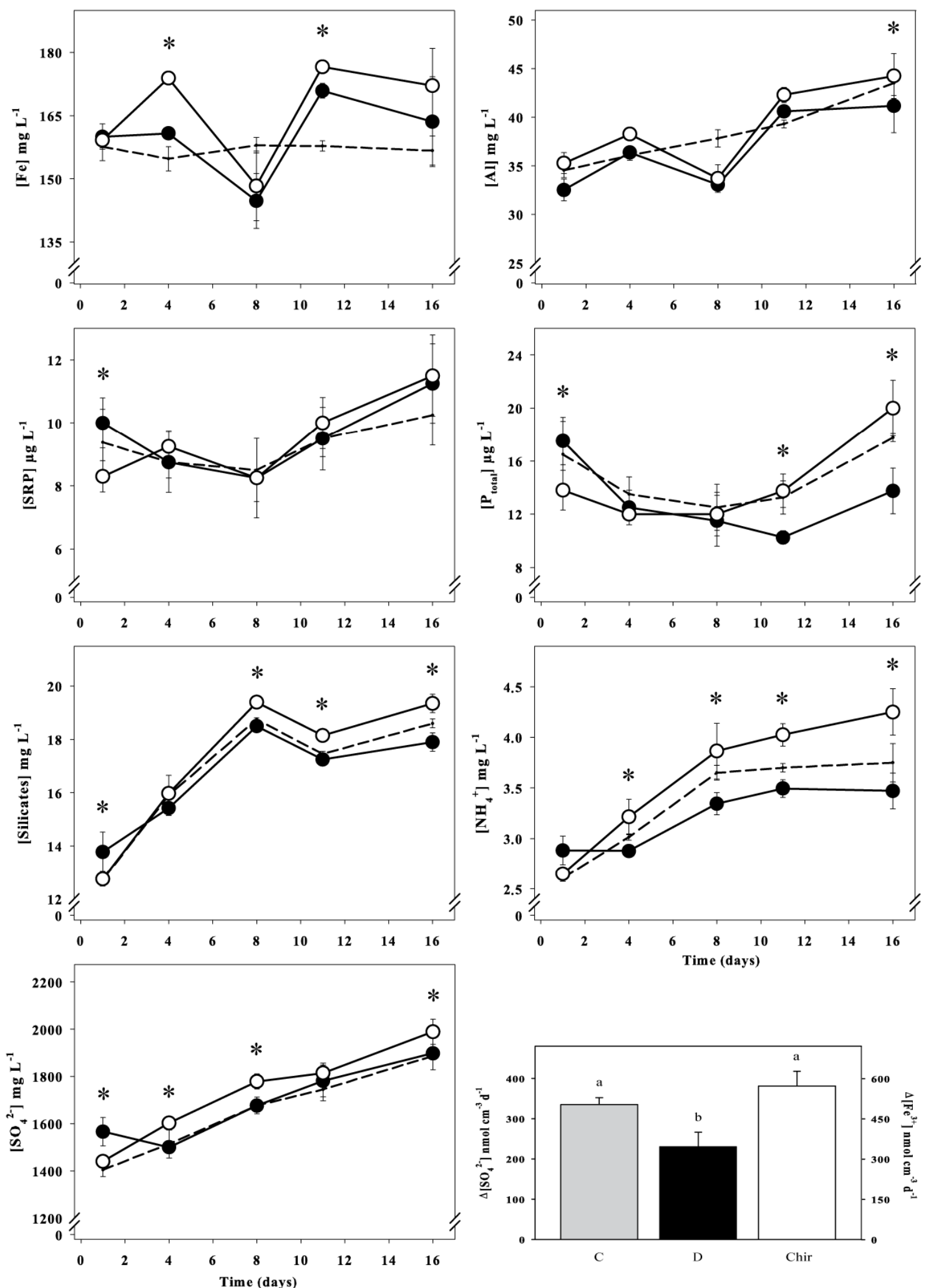

Fig. 2. Temporal variation of the concentrations of the main dissolved chemical species in the water column in the different treatments (Control: C, - - -; Defaunated: D, - •- ; with chironomids: Chir, $-\circ-)$. Means \pm SD $(N=4)$. Stars indicate significant differences between D- and Chir- treatments at each time of sampling. The bar chart represents the potential jarosite dissolution expressed as a net rate of sulfate and hypothetical ferric iron release. Means $\pm \mathrm{SD}(N=4)$. Different letters indicate significant differences between treatments. 

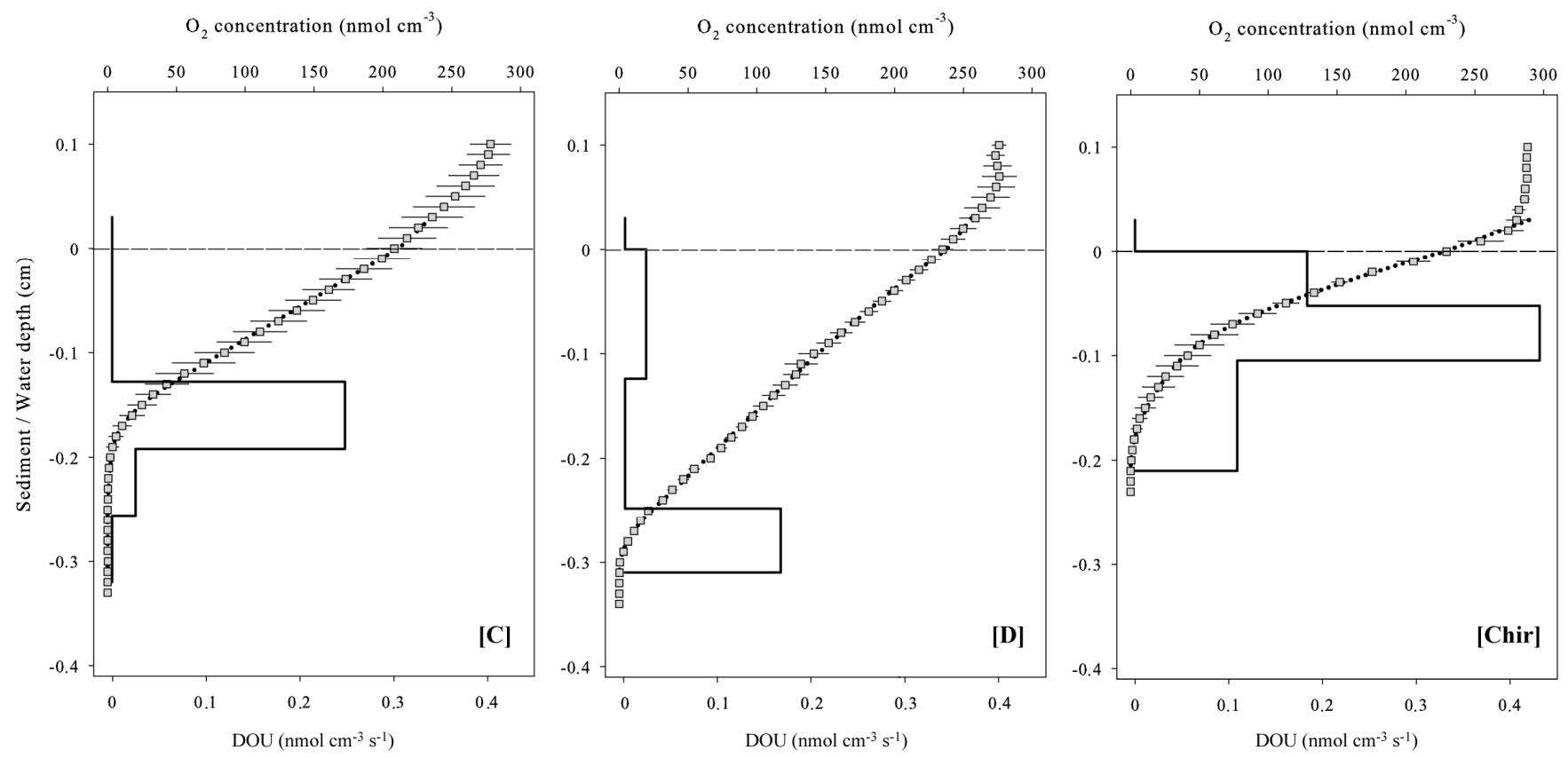

Fig. 3. Dissolved oxygen profiles and modelled oxygen consumption of sediment estimated in the different treatments using the software PROFILE (Control: C, Defaunated: D, with Chironomids: Chir). Grey dots are measured concentrations (Means \pm SD, $N=4$ ) and the dotted lines the fitted concentration profiles. The black lines show the oxygen consumption as a function of depth modelled from the concentration profiles. The horizontal dotted lines indicate the sediment-water interface.

(i) from the top to a depth of $13 \mathrm{~cm}$, a zone of slight consumption, (ii) and deeper, a zone of slight production. The profiles in control cores (C-cores) showed an intermediate state between the two previously described conditions.

The depth-integrated rates of $\mathrm{Fe}(\mathrm{II})$ production/consumption were almost half reduced in presence of chironomids: (i) from $7.9 \times 10^{-3} \mathrm{nmol} \mathrm{Fe} \mathrm{cm}^{-2} \mathrm{~s}^{-1}$ (D-cores) to $4.3-4.8 \times 10^{-3} \mathrm{nmol} \mathrm{Fe} \mathrm{cm}^{-2} \mathrm{~s}^{-1} \quad(\mathrm{C}-$ and Chir-cores) for production (i.e. iron reduction), and (ii) from $7.7 \times 10^{-3} \mathrm{nmol} \mathrm{Fe} \mathrm{cm}^{-2} \mathrm{~s}^{-1}$ (D-cores) to 4.4 $4.8 \times 10^{-3} \mathrm{nmol} \mathrm{Fe} \mathrm{cm}^{-2} \mathrm{~s}^{-1}$ (C- and Chir-cores) for consumption (i.e. upward-diffusion). However, in all cases, production and consumption of $\mathrm{Fe}$ (II) were in balance, resulting in no significant diffusive flux of dissolved iron over the sediment water interface. In defaunated sediment (D-cores), where these rates were higher, we observed a small peak of dissolved ferric iron around the oxicline, which is consistent with iron oxidation at that depth.

\subsection{Composition of the sediment}

The presence of chironomids had no significant effect on the distribution of the main solid chemical species in the upper $7 \mathrm{~cm}$ of the sediment (Fig. 5) (ANOVAs: $F_{2,9}=0.1$ to $3.1, p>0.05)$. There was only one remarkable difference for the Mn concentration in the 4-7 cm layer, with a significant higher value in presence of chironomids in the sediment (ANOVAs: $F_{2,9}=10.4, p=0.004$ ). Concerning the differences observed for silicates, as it separated C-treatment from the other treatments, it seems that only experimental conditions (e.g. defaunation by $\mathrm{N}_{2}$-bubbling) have reduced the sediment concentrations of this element (ANOVAs from $0-1$ to $4-7 \mathrm{~cm}$ layers: $F_{2,9}=5.5, p=0.027 ; F_{2,9}=5.5$, $p=0.027 ; F_{2,9}=19.9, p=0.000, F_{2,9}=9.1, p=0.007$; Fisher's LSD test: $p<0.05)$. The Si flux measured during the incubation (about $9 \mathrm{nmol} \mathrm{cm}{ }^{-3} \mathrm{~d}^{-1}$, from Fig. 2) was too low to explain the difference.

\subsection{Bacterial counts}

The counting of Fe-oxidizing bacteria $(\mathrm{FeOB})$ in the different layers of the top sediment (Fig. 6) revealed a high abundance in the upper $4 \mathrm{~cm}$ with a decrease as a function of depth. A significant effect of both treatment, depth and treatment $\times$ depth was observed (ANOVA: $F_{2,36}=22.5$, $F_{3,36}=112, F_{6,36}=7.3$, respectively; $\left.p<0.05\right)$. By comparing D- and Chir- treatments, the abundance of FeOB in the presence of chironomids was increased by a factor of around $\times 2000$ in the $0-1 \mathrm{~cm}$ layer (Fisher's LSD test: $p<0.05$ ), $\times 30000$ in the $1-2 \mathrm{~cm}$ layer (Fisher's LSD test: $p<0.05$ ) and $\times 45$ in the $2-4 \mathrm{~cm}$ layer (Fisher's LSD test: $p<0.05$ ), while no significant difference occurred below (Fisher's LSD test: $p=0.06$ ).

The most probable number of Fe-reducing bacteria (FeRB) in the top layers of sediment was largely lower than the number of FeOB (Fig. 6). However, two-way ANOVA 

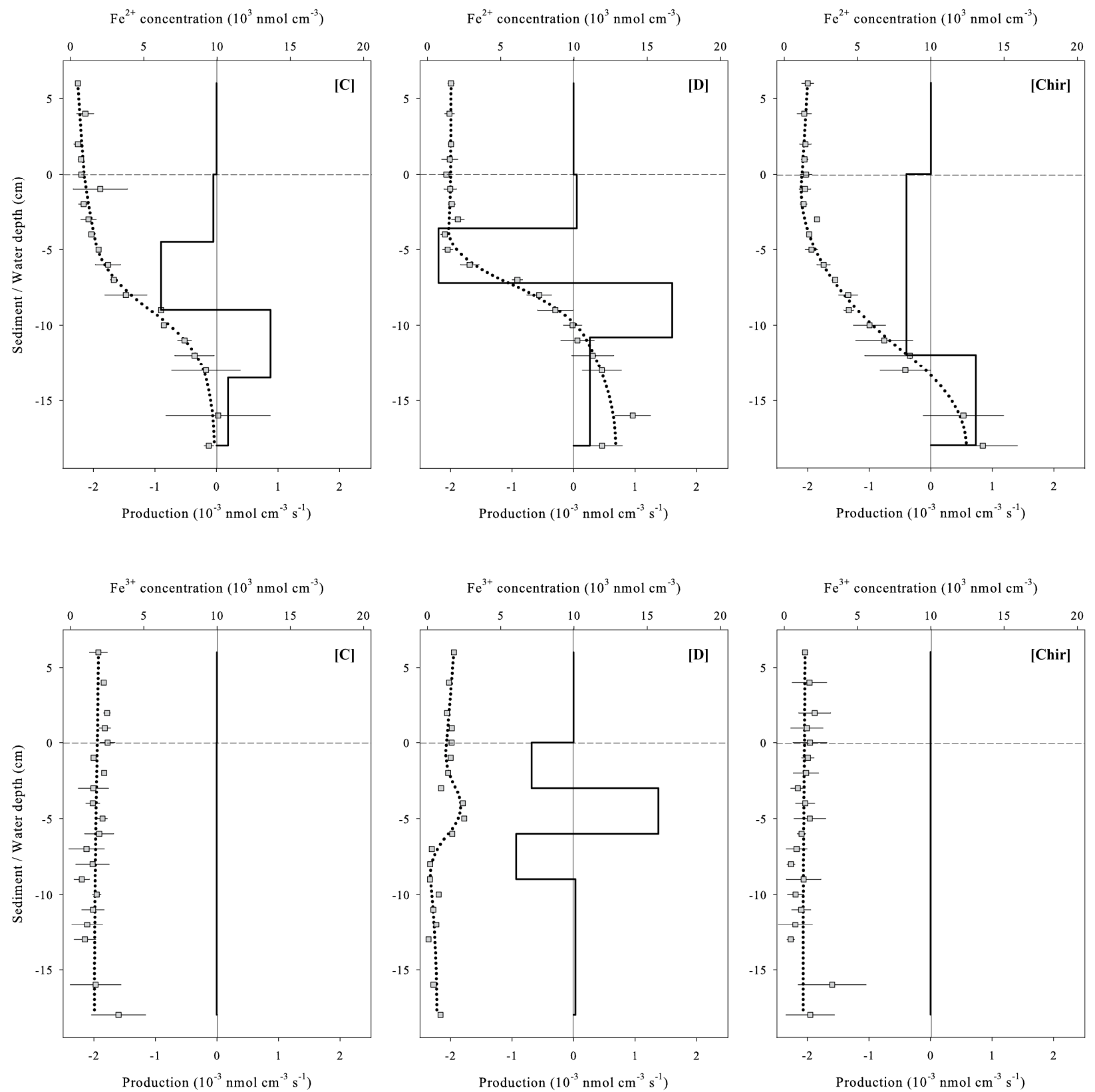

Fig. 4. Ferrous and ferric iron concentration profiles and production rates in the sediment estimated in the different treatments using the software PROFILE (Control: C, Defaunated: D, with chironomids: Chir). Grey dots are measured concentrations (Means $\pm \mathrm{SD}, N=4)$ and the dotted lines the fitted concentration profiles. The black lines show the production as a function of depth modelled from the concentration profiles. The horizontal dotted lines indicate the sediment-water interface.

also revealed an effect of treatment and depth, but not of treatment $\times$ depth (ANOVA: $F_{2,36}=5.01, p=0.01 ; F_{3,36}=$ 21.6, $\left.p=0.00 ; F_{6,36}=1.9, p=0.10\right)$. Even if a trend of increasing abundance in presence of chironomids was observed, it was only significant in the $2-4 \mathrm{~cm}$ layer, with a factor of $\times 8.5$ (Fisher's LSD test: $p=0.04$ ).

\section{Discussion}

\subsection{Ecology of Chironomus crassimanus in acidic mining lakes}

These first investigations of chironomid larva bioturbation in acidic environment revealed that the ecological patterns of these organisms are comparable to those described in other ecosystems. Maximal densities of population measured in 


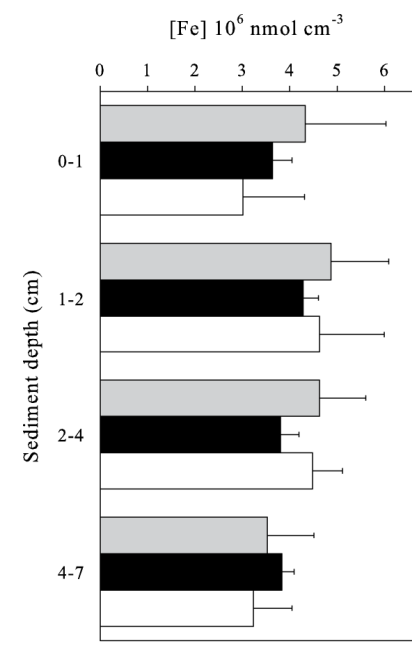

$\left[\mathrm{C}_{\text {part }}\right] \mathrm{mmol} \mathrm{cm}^{-3}$

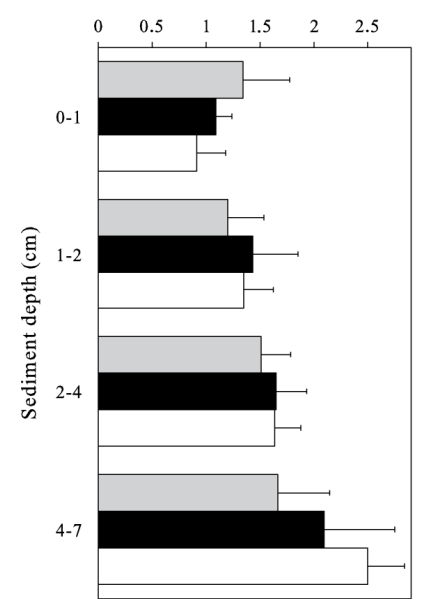

[Al] $10^{6} \mathrm{nmol} \mathrm{cm}^{-3}$

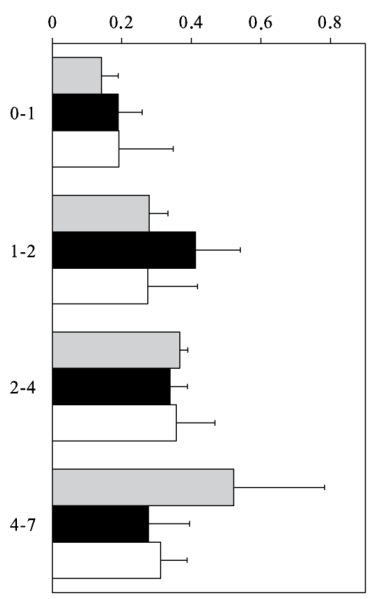

$\left[\mathrm{C}_{\text {org }}\right] \mathrm{mmol} \mathrm{cm}^{-3}$

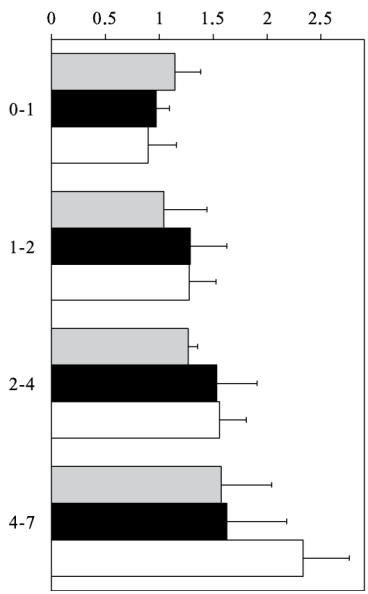

$[\mathrm{Mn}] \mathrm{nmol} \mathrm{cm}{ }^{-3}$

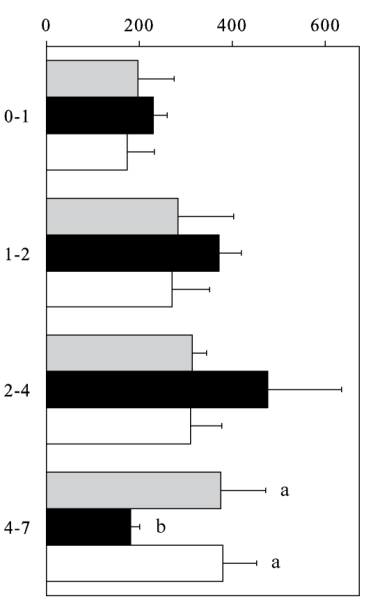

$\left[\mathrm{N}_{\mathrm{part}}\right] \mathrm{mmol} \mathrm{cm} \mathrm{cm}^{-3}$

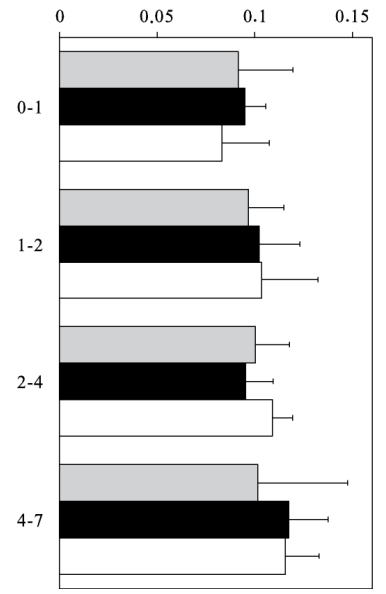

[Silicates] $\mu \mathrm{mol} \mathrm{cm} \mathrm{cm}^{-3}$

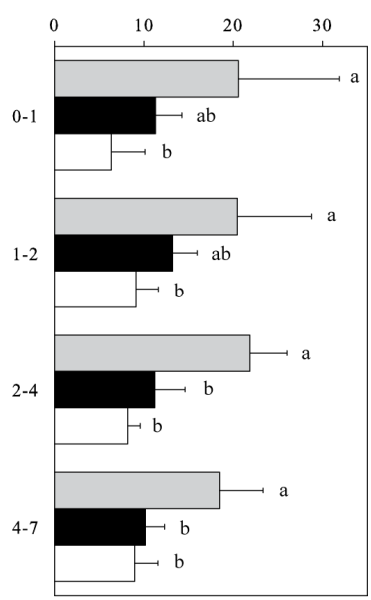

$\left[\mathrm{S}_{\text {part }}\right] \mathrm{mmol} \mathrm{cm}^{-3}$

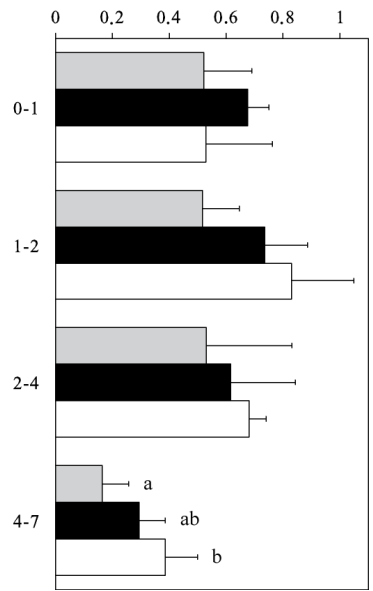

Fig. 5. Averaged content of the main solid chemical species in the first $7 \mathrm{~cm}$ of the sediment $(0-1,1-2,2-4$ and $4-7 \mathrm{~cm}$ layers $)$ per sediment volume at initial conditions (Control: C, grey bars) and after 16 days in the different treatments (Defaunated: D, black bars; with chironomids: Chir, white bars). Means \pm SD $(N=4)$. For the averaged data, $42 \pm 7 \%$ of sediment samples are explained by the analysis. Same letters or absence of letters on graphs indicate no significant difference between treatments.

the ML-111 are similar to mean values reported for chironomids in lacustrine environments (Armitage et al., 1995). At the 5 sampled transect sites, their presence was restricted to shallow littoral zones $(<4 \mathrm{~m})$ with maximal abundances under $2 \mathrm{~m}$ of water. Although chironomid larvae are known to potentially colonize sediment in the profundal, this distribution pattern is characteristic for benthos in oligo-mesotrophic lakes (Brinkhurst, 1974). The heterogeneous environment offered by rooted plants as well as better oxygen supply and a higher primary production by benthic algae in shallow bottoms probably favor the concentration of benthic organisms in these areas. Moreover, in oligotrophic lakes, most of the energy bound by photosynthesis in the upper water layers is utilized by respiration processes in the water and the particles deposited at the deep sediment surface are poor quality food (Hakanson and Jansson, 1983). It has been effectively re- ported that summer stratification of ML-111 leads to an oxygen decrease from $4 \mathrm{~m}$ of water depth (Meier et al., 2004). As well, the absence of predation and competition with other macro-invertebrates is likely to contribute to the concentration of chironomids in the littoral zone of the lake.

Like other species of the genus Chironomus, C. crassimanus was observed to burrow permanent tubes with intermittent pumping. However, roaming at the sediment surface was poorly observed and larva stayed in their tubes. This induced a low particle reworking in the upper $2-3 \mathrm{~cm}$ of sediment which is typical for freshwater bioirrigators such as chironomid larvae (Matisoff and Wang, 2000).

It should be noted, that chimney-like prolonging tubes above the sediment surface were observed during sediment sampling conducted for determination of chironomid densities in the lake. The chimneys were particularly numerous 

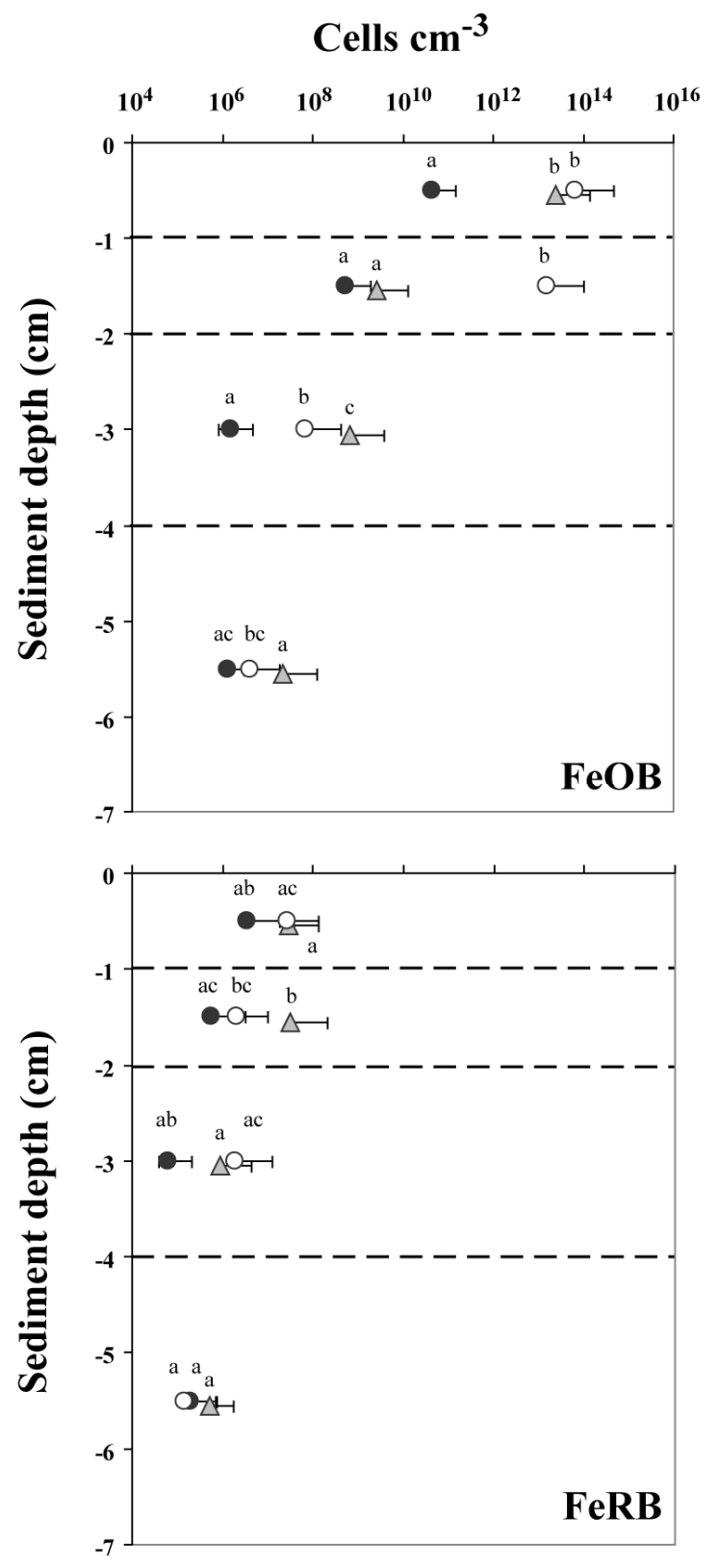

Fig. 6. $\mathrm{MPN}$ of $\mathrm{Fe}$-oxidizing bacteria $(\mathrm{FeOB})$ and $\mathrm{Fe}-$ reducing bacteria $(\mathrm{FeRB})$ in the first $7 \mathrm{~cm}$ of the sediment $(0-1,1-2,2-4$ and 4-7 cm layers) at initial conditions (Control: $\mathrm{C},-\Delta-$ ) and after 16 days in the different treatments (Defaunated: $\mathrm{D},-\bullet-$; with chironomids: Chir, $-\circ-)$. Means $\pm \mathrm{SD}(N=4)$. Same letters indicate no significant difference between treatments at each depth.

and extended $(2-3 \mathrm{~cm})$ in the sediment cores corresponding to deepest sampling points ( $4 \mathrm{~m}$ of water depth). As demonstrated by Stief et al. (2005), these sediment surface expansions permit higher oxygen availability for the larvae under hypoxic conditions. Under our laboratory conditions, the water column was constantly well-aerated and the chironomid tubes had only few millimeters of chimney-like expansions.

\subsection{Influence of bioturbation on oxygen dynamics and iron cycle}

The oxygen measurements demonstrated the influence of chironomid bioturbation on the global functioning of sediments. As previously described, the reduced oxygen penetration and the increasing diffusive oxygen uptake (DOU) are indicators of intense oxygen consumption through stimulation of heterotrophic microbial communities. According to respiration rates reported in the literature for chironomid larvae (Granéli, 1979), less than 15-20\% of the increased DOU can be accounted to larva metabolism requirements in our study. This enhancement is clearly linked to influence of bioturbation on organic matter decay and microbial metabolism (e.g. Svensson and Leonardson, 1996). The 3fold increase of DOU is of the same order of magnitude or even higher than results obtained in previous works with the same or lower densities of Chironomus species (e.g. Van de Bund et al., 1994; Hansen et al., 1997; Stief and De Beer, 2002; Lagauzère et al., 2009), indicating that the effect of bioturbation on acidic sediments can not be neglected. The PROFILE estimations demonstrated that the portion of DOU linked to the oxidation of upward diffusing ferrous iron was considerably reduced in presence of chironomids (from 79\% in D-cores to $26 \%$ in Chir-cores). Nevertheless, due to a higher total DOU, this part accounted for the same absolute rate in both undisturbed $\left(10.4 \times 10^{-3} \mathrm{nmol} \mathrm{O}_{2} \mathrm{~cm}^{-3} \mathrm{~s}^{-1}\right.$ in D-cores $)$ and bioturbated $\left(11.3 \times 10^{-3} \mathrm{nmol} \mathrm{O}_{2} \mathrm{~cm}^{-3} \mathrm{~s}^{-1}\right.$ in Chir-cores) sediments. Thus, chironomids increased aerobic mineralization of organic matter but not iron oxidation.

The PROFILE modelling of iron profiles indicated a sink of dissolved ferrous iron around $5 \mathrm{~cm}$ of sediment depth. Since molecular oxygen penetrated only $3 \mathrm{~mm}$ deep into the sediment the disappearance of ferrous iron cannot be explained by direct oxidation by oxygen. An oxygen supply to the deeper sediment due to chironomid activity or tubes was probably not relevant since the effect was most pronounced in the chironomid-free treatment. There are two possible explanations for the disappearance of ferrous iron in the sediment: (i) precipitation of a ferrous/ferric iron mineral, and (ii) oxidation of ferrous iron - by an oxidant other than oxygen - and subsequent precipitation of ferric iron mineral. Speciation calculations using PHREEQC showed that porewater was undersaturated with respect to the formation of green rusts (i.e. combined $\mathrm{Fe}^{2+} / \mathrm{Fe}^{3+}$ hydroxides).

Once the mechanism of $\mathrm{Fe}^{2+}$ oxidation by Mn was established, PHREEQC showed that porewater is saturated in $\mathrm{FeOOH}, \mathrm{Fe}(\mathrm{OH})_{3}$ and schwertmannite. Sulfide precipitation can be ruled out since microbial sulphate reduction was never observed in the acidic sediment of ML111 (Meier et al., 2004). Theoretically ferrous iron can also be removed from solution by the formation of mixed $\mathrm{Fe}^{\mathrm{II}} / \mathrm{Fe}^{\mathrm{III}}$ minerals like magnetite or green rusts (Génin et al., 1998). The porewater, however, was strongly undersaturated with respect to 
$\mathrm{Fe}_{4}(\mathrm{OH})_{8} \mathrm{Cl}$ and $\mathrm{Fe}_{6}(\mathrm{OH})_{12} \mathrm{SO}_{4}$. Thus, it is unprobable that precipitation of ferrous minerals occurred in our experiment.

Mn-oxides can oxidized iron (Postma and Appelo, 2000). Considering that all initial manganese was in the form of $\mathrm{MnO}_{2}$ and $\mathrm{pe}=11.53\left(\mathrm{pe}=\mathrm{Eh} / 0.059\right.$ at $25^{\circ} \mathrm{C}, \mathrm{Eh}=0.6803$ Volts), PHREEQC calculations show that all the $\mathrm{MnO}_{2}$ was dissolved and the speciation of $\mathrm{Fe}^{2+} / \mathrm{Fe}^{3+}$ coincides mostly with the concentrations observed in our experiments. We conclude that the vertical profiles of ferrous iron were probably not controlled by the precipitation of ferrous minerals but by oxidation by manganese.

In the presence of chironomids the profile of ferrous iron was more "stretched". This was probably caused by the rapid transport of $\mathrm{Fe}, \mathrm{Mn}$ and organic matter (i.e. particle advection) from the top of sediment towards the bottom of tubes $(3 \mathrm{~cm})$ and even deeper by displacement of larvae in sediment $(6 \mathrm{~cm})$.

Unlike us, Lewandoswki et al. (2007) observed a higher diffusive flux of iron to the water in presence of chironomids. To our knowledge, that study represents the only available reference of chironomid influence on iron cycle in the literature. The authors suggested that bioturbation leads to an intense iron cycle below the sediment-water interface and in the burrow walls. Ferrous iron diffuses according to its gradient from the sediment to the burrows and the overlying water but oxygen diffuses on the opposite sense leading to oxidation and subsequent precipitation of oxyhydroxides of ferric iron. This redox reaction occurs close to the oxicanoxic boundary and iron is immobilized in the sediment or deposits in particulate form at the sediment surface. From 2D-profiling of ion concentrations, Lewandoswki et al. (2007) demonstrated that the burrow walls were surrounded by low concentrations of dissolved $\mathrm{Fe}^{2+}$ and then contribute locally to iron oxidation within the anoxic bulk sediment. Our DET approach could not resolve this 2-D pattern and hides the horizontal heterogeneity. As suggested by higher abundances of Fe-oxidizing bacteria $(\mathrm{FeOB})$ in sediment layers occupied by chironomids, it can be assumed that oxidation effectively occurred in burrows and that the turn-over was locally higher. Indeed, besides a higher nutrient and oxygen availability, chironomid larvae yield also labile and fresh organic matter (e.g. mucus, faeces) within sub-surface sediments that make their burrows favorable habitats for certain microbial communities (Stief and De Beer, 2002; Stief et al., 2005; Gerbersdorf et al., 2008). Despite these considerations, integrated rates of production/consumption of iron in the whole sediment column were balanced and the global turn-over remained unchanged.

To understand the influence of macro-invertebrate on the distribution of metallic compounds, the two modalities of bioturbation (e.g. particulate transport and solute transport) should be considered because they induce different effects: (i) the particulate transport carries associated metals through different areas in the sediment, including the digestive tract of organisms (deposit-feeders), (ii) the irrigation of burrows
Table 2. Effects of chironomid larvae on sediment biogeochemistry.

\begin{tabular}{ll}
\hline Parameter & Effect \\
\hline $\mathrm{O}_{2}$ consumption & Increased \\
Organic matter oxidation & Increased \\
$\mathrm{NH}_{4}^{+}$flux & Increased \\
$\mathrm{Fe}$-turnover & Lower rates of oxidation \\
& $\begin{array}{l}\text { and reduction Stimulation } \\
\text { of mineral transformations }\end{array}$ \\
Bacterial abundance & Iron oxidizer abundance increased \\
Fe-flux & No effect \\
\hline
\end{tabular}

transports metallic compounds, either dissolved or associated to the organic matter, from the water to the sediment, often leading to a gross flux through the sediment-water interface and affecting the adsorption/desorption kinetics. As defined by Gérino et al. (2003), chironomid larvae belong to the bioturbation functional group of bioirrigators and therefore have limited effect on particulate transport. Their presence induces a diffusive-like mixing in the top sediment surrounding burrows, and an advective transport between the sedimentwater interface and the bottom of tubes due to organism displacements and faecal ejections ("non-local transport"). Our results are in accordance with these considerations as no difference of the particulate iron (as well as aluminium or manganese) distribution was observed in presence of chironomid larvae in the sediment (Fig. 6). On the other hand, although the dissolved flux of iron at the sediment-water interface was unchanged (i.e. absence of flux in all treatments; Fig. 4), the concentration of total iron in the water tends to be higher with chironomid larvae in the sediment (Fig. 2). Iron transport over the sediment-water interface was obviously only by advection. Several studies reported release of metals through particle resuspension due to burrowing and faecal ejection of chironomid larvae (e.g. De Haas et al., 2005), but in our case this observation was probably limited by the concomitant precipitation of iron at the sediment surface since the water was well oxygenated. In conclusion, irrigation or advection by chironomid larvae did not result in a net transport of iron from the sediment to the bottom water.

We observed a flux of sulfate from the sediment into the water. It is well known that in the sediments of acidic pit mine lakes the initially formed hydroxysulfates, jarosite and schwertmannite, subsequently transformed into goethite while releasing sulfate and protons (Regenspurg et al., 2004). The release of sulfate from sediment containing schwertmannite has been observed by several authors such as Jönsson et al. (2005) and Acero et al. (2006). In laboratory experiments performed by Acero et al. (2006) a sulphate efflux of $543 \mathrm{nmol} \mathrm{cm}^{-3} \mathrm{~d}^{-1}$ was observed (Jönsson et al., 2005) which is very similar to the fluxes observed in our study (230-381 $\left.\mathrm{nmol} \mathrm{cm}^{-3} \mathrm{~d}^{-1}\right)$. The effect was more pronounced 
in presence of chironomids (ANOVA: $F_{2,9}=24.1, p<0.05$; Fisher's LSD test: $p<0.05)$. Bioturbation obviously speeds up the transformation of iron-hydroxosulfates and thus, may stimulate sulfate and proton release from the sediment.

\subsection{Consequences on sediment and water quality}

Chironomid larva induced only moderate modifications of their environment. The distribution of particulate elements in the sediment surrounding burrows (upper $7 \mathrm{~cm}$ ) was not affected (Fig. 6). However, the data of water analyses permitted to put in evidence some processes (Fig. 2). For all measured parameters, concentrations increased during the experiment indicating a flux out of the sediment in all treatments and thus a non-steady state of the system. Differences were significant between $\mathrm{D}$ - and Chir-treatments indicating that the bioturbation of chironomid larvae tends to modify the water quality by stimulating the release of nutrients and, with a lower intensity, the release of metals. A portion might account to excretion of phosphorus and ammonium by the larvae $(\sim 10-15 \%$, based on equations from Fukuhara and Yasuda, 1985, 1989). Therefore, the outward flux of solutes from the sediment can be explained by a number of other processes: (i) higher fluxes due to increasing sediment-water interface area and pumping of water in and out of burrows (i.e. bioirrigation), (ii) production of metabolites from increased organic matter mineralization, and (iii) resuspension of sediment particles due to burrowing activities or faecal production and subsequent oxidation/dissolution of particleassociated elements (e.g. Matisoff and Wang, 2000; De Haas et al., 2005; Lewandowski et al., 2007). The stimulation of mineral transformation as indicated by a higher sulfate flux might have led to the mobilization of adsorbed phosphorous. The consequence of bioturbation on the phosphorous flux remains a matter of controversy since both stimulation (Krantzberg, 1985) and reduction (Lewandowski et al., 2007) were observed.

\section{Conclusions}

This study provides the first observation of benthic macroinvertebrate bioturbation in an acidic mining lake. Despite a low biodiversity, the presence of an adapted pioneer species like Chironomus crassimanus has an influence on the biogeochemistry of the sediment (Table 2). Taking all observations together, it seems that in the sediments of the acidic Mining Lake 111 chironomids clearly stimulate the turnover of organic matter but not of iron. Since complete $\mathrm{C}_{\mathrm{org}}$ mineralisation to $\mathrm{CO}_{2}$ by $\mathrm{O}_{2}$ does not change the alkalinity status of the system, bioturbation has little influence on the acidity budget of the lake. While their influence on the lakes carbon cycle cannot be ignored, chironomids obviously have a minor influence on iron cycling in acidic pit mine lakes. Contrary to our hypothesis, chironomids did not stim- ulate iron cycling in the sediment. Bioturbation affected the sediment internal cycling of iron but had little influence on sediment-water exchange.

The presence of other benthic macro-invertebrate species in acidic lakes is reported in the literature (Rodriguez and Scharf, 2001). Some of them belong to taxa with known bioturbation activity (e.g. Trichoptera, Ephemeroptera, Plecoptera, Megaloptera). The present study highlights that their effects should be taken into account in further studies dealing with biogeochemistry of acidic lakes.

Acknowledgements. The authors want to sincerely thank Corrina Völkner, Martin Wieprecht, Marion Ludwig, and Matthias Müller for field sampling and technical assistance throughout all the experimental investigations; Jutta Meier and Katrin Wendt-Potthoff for their implication in the research project; and Xavier-François Garcia for chironomid identification. Two anonymous reviewers are acknowledged for their valuable comments on earlier drafts of the manuscript.

Edited by: A. Boetius

\section{References}

Acero, P., Ayora, C., Torrentó, C., and Nieto, J. M.: The behavior of trace elements during schwertmannite precipitation and subsequent transformation into goethite and jarosite, Geochim. Cosmochim. Ac., 70, 4130-4139, 2006.

Andersen, F. and Kristensen, E.: The importance of benthic macrofauna in decomposition of microalgae in a coastal marine sediment, Limnol. Oceanogr., 37, 1392-1403, 1992.

Armitage, P. D., Cranston, P. S., and Pinder, L. C. V. (Eds.): The Chironomidae: The biology and ecology of non-biting midges, Chapman and Hall, London, UK, 1995.

Berg, P., Risgaard-Petersen, N., and Rysgaard, S.: Interpretation of measured concentration profiles in sediment pore water, Limnol. Oceanogr., 43, 1500-1510, 1998.

Blodau, C.: A review of acidity generation and consumption in acidic coal mine lakes and their watersheds, Sci. Total Environ., 369, 307-332, 2006.

Brinkhurst, R. O.: The benthos of lakes, Macmillan, London, UK, 1974.

Brune, A., Frenzel, P., and Cypionka, H.: Life at the oxic-anoxic interface: microbial activities and adaptations, FEMS Microbiol. Rev., 24, 691-710, 2000.

De Haas, E. M., Kraak, M. H. S., Koelmans, A. A., and Admiraal, W.: The impact of sediment reworking by opportunistic chironomids on specialised mayflies, Freshwater Biol., 50, 770780, 2005.

Fukuhara, H. and Yasuda, K.: Phosphorus excretion by some zoobenthos in a eutrophic freshwater lake and its temperature dependency, The Japanese Journal of Limnology, 46, 287-296, 1985.

Fukuhara, H. and Yasuda, K.: Ammonium excretion by some freshwater zoobenthos from a eutrophic lake, Hydrobiologia, 173, 18, 1989.

Geller, W., Klapper, H., and Schultze, M.: Natural and anthropogenic sulfuric acidification of lakes, in: Acid Mining Lakes 
- Acid Mine Drainage, Limnology and Reclamation, edited by: Geller, W., Klapper, H., and Salomons, W., Springer, Berlin, Germany, 3-14, 1998.

Geller, W., Koschorreck, M., Schultze, M., Wendt-Potthoff, K., and Gene, E. L.: Restoration of acid drainage, in: Encyclopedia of Inland Waters, Academic Press, Oxford, UK, 342-358, 2009.

Génin, J.-M. R., Bourrie, G., Trolard, F., Abdelmoula, M., Jaffrezic, A., Refait, P., Maitre, V., Humbert, B., and Herbillon, A.: Thermodynamic equilibria in aqueous suspensions of synthetic and natural $\mathrm{Fe}(\mathrm{II})-\mathrm{Fe}(\mathrm{III})$ green rusts: Occurrences of the mineral in hydromorphic soils, Environ. Sci. Technol., 32, 1058-1068, 1998.

Gerbersdorf, S. U., Jancke, T., Westrich, B., and Paterson, D. M.: Microbial stabilization of riverine sediments by extracellular polymeric substances, Geobiology, 6, 57-69, 2008.

Gérino, M., Vervier, P., Stora, G., Gilbert, F., Poggiale, J.-C., François-Carcaillet, F., Mermillod-Blondin, F., and Desrosiers, G.: Macro- invertebrate functional groups in freshwater and marine sediments: A common mechanistic classification, Vie Milieu, 53, 221-232, 2003.

Granéli, W.: The influence of Chironomus plumosus on the oxygen uptake of sediment, Arch. Hydrobiol., 87, 385-403, 1979.

Hakanson, L. and Jansson, M.: Principles of Lake Sedimentology, The Blackburn Press, New York, USA, 1983.

Hansen, K., Mouridsen, S., and Kristensen, E.: The impact of Chironomus plumosus larvae on organic matter decay and nutrient $(\mathrm{N}, \mathrm{P})$ exchange in a shallow eutrophic lake sediment following a phytoplankton sedimentation, Hydrobiologia, 364, 65-74, 1997.

Herzsprung, P., Bozau, E., Büttner, O., Duffek, A., Friese, K., Koschorreck, M., Schultze, M., v. Tümpling, W., and WendtPotthoff, K.: Routine analysis of sediment pore water of high ionic strength, Acta Hydroch. Hydrob., 34, 593-607, 2006.

Hünken, A. and Mutz, M.: On the ecology of the filter-feeding Neureclipsis bimaculata (Trichoptera, Polycentropodidae) in an acid and iron rich post-mining stream, Hydrobiologia, 592, 135$150,2007$.

ISO 6878:2004: Water quality - Determination of phosphorus Ammonium molybdate spectrometric method; International Organization for Standardization, 21 pp., 2004.

Jönsson, J., Persson, P., Sjöberg, S., and Lövgren, L.: Schwertmannite precipitated from acid mine drainage: phase transformation, sulphate release and surface properties, Appl. Geochem., 20, 179-191, 2005.

Kajan, R. and Frenzel, P.: The effect of chironomid larvae on production, oxidation and fluxes of methane in a flooded rice soil, FEMS Microbiol. Ecol., 28, 121-129, 1999.

Kamjunke, N., Tittel, J., Krumbeck, H., Beulker, C., and Poerschmann, J.: High Heterotrophic Bacterial Production in Acidic, Iron-Rich Mining Lakes, Microb. Ecol., 49, 425-433, 2005.

Klee, A. J.: A computer program for the determination of most probable number and its confidence limits, J. Microbiol. Meth., 18, 91-98, 1993.

Knöller, K., Fauville, A., Mayer, B., Strauch, G., Friese, K., and Veizer, J.: Sulfur cycling in an acid mining lake and its vicinity in Lusatia, Germany, Chem. Geol., 204, 303-323, 2004.

Koschorreck, M., Brookland, I., and Matthias, A.: Biogeochemistry of the sediment-water interface in the littoral of an acidic mining lake studied with microsensors and gel-probes, J. Exp. Mar. Biol. Ecol., 285-286, 71-84, 2003.
Koschorreck, M., Bozau, E., Frommichen, R., Geller, W., Herzsprung, P., and Wendt-Potthoff, K.: Processes at the sediment water interface after addition of organic matter and lime to an acid mine pit lake mesocosm, Environ. Sci. Technol., 41, 1608-1614, 2007.

Krantzberg, G.: The influence of bioturbation on physical, chemical and biological parameters in aquatic environments: a review, Environ. Pollut., 39, 99-122, 1985.

Kristensen, E.: Organic matter diagenesis at the oxic/anoxic interface in coastal marine sediments, with emphasis on the role of burrowing animals, Hydrobiologia, 426, 1-24, 2000.

Lagauzère, S., Pischedda, L., Cuny, P., Gilbert, F., Stora, G., and Bonzom, J.-M.: Influence of Chironomus riparius (Diptera, Chironomidae) and Tubifex tubifex (Annelida, Oligochaeta) on oxygen uptake by sediments. Consequences of uranium contamination, Environ. Pollut., 157, 1234-1242, 2009.

Lessmann, D., Deneke, R., Ender, R., Hemm, M., Kapfer, M., Krumbeck, H., Wollmann, K., and Nixdorf, B.: Lake Plessa 107 (Lusatia, Germany) - an extremely acidic shallow mining lake, Hydrobiologia, 408-409, 293-299, 1999.

Lewandowski, J., Laskov, C., and Hupfer, M.: The relationship between Chironomus plumosus burrows and the spatial distribution of pore-water phosphate, iron and ammonium in lake sediments, Freshwater Biol., 52, 331-343, 2007.

Li, Y. and Gregory, S.: Diffusion of ions in sea water and in deepsea sediments, Geochim. Cosmochim. Ac., 38, 703-714, 1974.

Matisoff, G. and Wang, X.: Particle mixing by freshwater infaunal bioirrigators: midges (Chironomidae:diptera) and mayflies (Ephemeridae:Ephemeroptera), J. Great Lakes Res., 26, 174$182,2000$.

Meier, J., Babenzien, H.-D., and Wendt-Potthoff, K.: Microbial cycling of iron and sulfur in sediments of acidic and $\mathrm{pH}$-neutral mining lakes in Lusatia (Brandenburg, Germany), Biogeochemistry, 67, 135-156, 2004.

Mermillod-Blondin, F. and Rosenberg, R.: Ecosystem engineering: The impact of bioturbation on biogeochemical processes in marine and freshwater benthic habitats, Aquat. Sci., 68, 434-442, 2006.

Parkhurst, D. L. and Appelo, C. A. J.: PHREEQC (version 2) - a computer program for speciation, batch-reaction, onedimensional transport, and inverse geochemical calculations, 2nd edn., U.S. Geological Survey, Denver, Colorado, 1999.

Peine, A., Tritschler, A., Kusel, K., and Peiffer, S.: Electron flow in an iron-rich acidic sediment - Evidence for an acidity-driven iron cycle, Limnol. Oceanogr., 45, 1077-1087, 2000.

Polerecky, L., Volkenborn, N., and Stief, P.: High temporal resolution oxygen imaging in bioirrigated sediments, Environ. Sci. Technol., 40, 5763-5769, 2006.

Postma, D. and Appelo, C. A. J.: Reduction of Mn-oxides by ferrous iron in a flow system: Column experiment and reactive transport modelling, Geochim. Cosmochim. Ac., 64, 1237-1247, 2000.

Regenspurg, S., Brand, A., and Peiffer, S.: Formation and stability of schwertmannite in acidic mining lakes, Geochim. Cosmochim. Ac., 68, 1185-1197, 2004.

Revsbech, N. P. and Jørgensen, B. B.: Microelectrodes: Their use in microbial ecology, Adv. Microb. Ecol., 9, 293-351, 1986.

Rodriguez, G. G.: Benthic fauna of extremely acidic lakes ( $\mathrm{pH} 2-3$ ), Ph.D. thesis, Technical University of Braunschweig, Germany, 
138 pp., 2001.

Rodriguez, G. G. and Scharf, B. W.: Review of benthic invertebrate fauna in extremely acidic environments $(\mathrm{pH} \leq 3)$, Mine Water and the Environment, 20, 114-121, 2001.

Schultze, M., Geller, W., Wendt-Potthoff, K., and Benthaus, F. C.: Management of water quality in German pit lakes, 15 pp., http: //Proceedings-stfandicard-2009.com, 2009.

Stief, P.: Enhanced exoenzyme activities in sediments in the presence of deposit-feeding Chironomus riparius larvae, Freshwater Biol., 52, 1807-1819, 2007.

Stief, P. and De Beer, D.: Bioturbation effects of Chironomus riparius on the benthic $\mathrm{N}$-cycle as measured using microsensors and microbiological assays, Aquat. Microb. Ecol., 27, 175-185, 2002.

Stief, P., Nazarova, L., and De Beer, D.: Chimney construction by Chironomus riparius larvae in response to hypoxia: Microbial implications for freshwater sediments, J. N. Am. Benthol. Soc., 24, 858-871, 2005.

Svensson, J. M.: Influence of Chironomus plumosus larvae on ammonium flux and denitrification (measured by the acetylene blockage- and the isotope pairing-technique) in eutrophic lake sediment, Hydrobiologia, 346(1-3), 157-168, 1997.
Svensson, J. M. and Leonardson, L.: Effects of bioturbation by tube-dwelling chironomid larvae on oxygen uptake and denitrification in eutrophic lake sediments, Freshwater Biol., 35(2), 289300, 1996.

Van de Bund, W. J., Goedkoop, W., and Johnson, R. K.: Effects of deposit-feeder activity on bacterial production and abundance in profundal lake sediment, J. N. Am. Benthol. Soc., 13, 532-539, 1994.

Warren, L. A. and Haack, E. A.: Biogeochemical controls on metal behaviour in freshwater environments, Earth-Sci. Rev., 54, 261320, 2001.

Wendt-Potthoff, K. and Koschorreck, M.: Functional groups and activities of bacteria in a highly acidic volcanic mountain stream and lake in Patagonia, Argentina, Microb. Ecol., 43(1), 92-106, 2002.

Wollmann, K., Deneke, R., Nixdorf, B., and Packroff, G.: Dynamics of planktonic food webs in three mining lakes across a $\mathrm{pH}$ gradient (pH 2-4), Hydrobiologia, 433, 3-14, 2000. 